\title{
Association of glucose-6-phosphate dehydrogenase deficiency with diabetes mellitus in ethnic groups of Singapore
}

\author{
N. SAHA \\ From the Department of Physiology, Faculty of Medicine, University of Singapore, Singapore
}

SUMMARY Six hundred and nine male patients suffering from maturity onset diabetes mellitus, comprising 422 Chinese, 66 Malays, and 121 Indians, were investigated to determine the incidence of G6PD deficiency, ABO blood groups, and haemoglobin types, and these were compared with normal healthy controls. A positive association with a higher incidence of G6PD deficiency in diabetics was observed in Chinese and Indian patients. There was no significant difference in the frequencies of $\mathrm{ABO}$ blood groups and haemoglobin types between the patients and the controls in any of the ethnic groups studied.

The genetic association of diabetes mellitus has been studied in the past mainly by the relative incidence of blood groups and serum proteins (Craig and Wang, 1955; McConnell et al., 1956; Andersen and Lauritzen, 1960; Macafee, 1964; Berg et al., 1967; Klebe and Nielsen, 1972; Lamba et al., 1974), but the results, far from being in agreement, are rather conflicting. From an epidemiological study into the incidence of cancer and diabetes mellitus and glucose-6-phosphate dehydrogenase (G6PD) deficiency in different populations of the world, Kessler (1970) suggested a negative association of G6PD deficiency in cancer and a positive relationship in diabetes mellitus. Naik and Anderson (1971) observed a negative association of G6PD deficiency in cancer in American Negro patients, but only in the case of females. In an earlier study on a pooled sample of smaller size we failed to observe any association of G6PD deficiency and ABO blood groups in diabetes mellitus (Saha, 1971). The three ethnic groups in Singapore (Chinese, Malays, and Indians), who have different incidences of the disease, with a higher incidence among Indians compared with the other two (Cheah et al., 1972, 1975), provided an excellent opportunity to study the possible association of G6PD deficiency, ABO blood groups, and haemoglobin types in diabetes mellitus.

We present in this report the incidence of G6PD deficiency, ABO blood groups, and haemoglobin types in maturity onset diabetes mellitus compared with healthy controls in the three ethnic groups of Singapore.

Received for publication 16 February 1979

\section{Materials and methods}

PATIENTS

Six hundred and nine male patients, comprising 422 Chinese, 66 Malays, and 121 Indians, attending the Diabetic Clinic at the Tan Tock Seng Hospital, Singapore, were investigated for the distribution of G6PD deficiency, ABO blood groups, and haemoglobin types. These were consecutive cases of maturity onset diabetes mellitus as confirmed by standard glucose tolerance tests after oral glucose. Five diabetic patients with G6PD deficiency at the first test were followed up and tested for blood glucose levels and G6PD deficiency on three or four subsequent visits while undergoing treatment.

\section{CONTROLS}

For comparison, controls were taken from (a) patients proved to be normal and (b) series in published reports.

(a) Seven hundred and forty seven male subjects comprising 523 Chinese, 87 Malays, and 137 Indians attending the same diabetic clinic formed the control series. These were consecutive cases confirmed as non-diabetic by standard glucose tolerance tests. They were investigated for the distribution of G6PD deficiency, ABO blood groups, and haemoglobin types.

(b) Published data. ABO blood groups were compared with the series of Chan (1962), cases of G6PD deficiency with the series of Saha and Banerjee (1971a, b), and for comparison with 
abnormal haemoglobins the series of Saha et al. (1973) were taken as healthy controls.

ABO blood grouping was carried out by slide tests using commercial antisera. G6PD deficiency was identified by the dye decoloration method of Motulsky and Campbell-Kraut (1961). Haemoglobin phenotypes were screened by paper electrophoresis using barbital buffer $\mathrm{pH} 8 \cdot 6$, ionic strength 0.025 .

\section{Results and discussion}

\section{G6PD DEFICIENCY}

Table 1 shows the distribution of G6PD deficiency in diabetic patients and healthy controls in the three ethnic groups. The incidence of G6PD deficiency is significantly higher in diabetic Chinese and Indian patients $(10.4 \%$ and $9.9 \%)$ compared to nondiabetic controls attending the diabetic clinic $(5.0 \%$ and $2.9 \%)$ and published series $(3.3 \%$ and $1.7 \%)$. The $P$ values are 0.002 and 0.04 , respectively, in the case of the former, and $0.16 \times 10^{-10}$ and 0.0001 in the case of the latter comparison. The relative risk of getting diabetes in G6PD deficient subjects is $2 \cdot 2$ and 3.4 in Chinese and 3.4 and 6.3 in Indians compared with non-deficient subjects in the diabetic clinic and population controls. This association of G6PD deficiency with diabetes mellitus holds up even when the three ethnic groups are combined $(P=0.007)$. Further, there is no significant heterogeneity between the two comparisons based on the two different controls in Chinese, Indians, and the combined group $(P=0.08,0.59$, and $0 \cdot 15$, respectively). There is no apparent significant difference in G6PD deficiency in the ethnic groups studied, and there is no significant difference in the case of Malays, which may be because of the small size of the sample.

In an earlier study we failed to observe any significant difference in the incidence of G6PD deficiency between diabetics and controls (Saha, 1971). This was probably because this was a pooled sample of all ethnic groups together. The present report suggests that there is an association of G6PD deficiency with diabetes mellitus which is in agreement with the hypothesis put forward by Kessler
Table 1b Data for association and relative risk*

\begin{tabular}{|c|c|c|c|c|}
\hline & & Chinese & Malays & India两 \\
\hline $\begin{array}{l}\text { Diabetic clinic } \\
\text { controls }\end{array}$ & $\begin{array}{l}\chi^{2} \\
\mathbf{P} \\
\text { Relative risk }\end{array}$ & $\begin{array}{l}10 \cdot 13 \\
0 \cdot 0022 \\
2 \cdot 20\end{array}$ & $\begin{array}{l}0.37 \\
0.79 \\
0.69\end{array}$ & $\begin{array}{l}5.40 \overline{\overline{7}} \\
0.038 \\
3.39 \text { 을 }\end{array}$ \\
\hline $\begin{array}{l}\text { Population } \\
\text { controls }\end{array}$ & $\begin{array}{l}\chi^{2} \\
\mathbf{P} \\
\text { Relative risk }\end{array}$ & $\begin{array}{c}47 \cdot 10 \\
0 \cdot 16 \times \\
10^{-10} \\
3 \cdot 38\end{array}$ & $\begin{array}{l}1 \cdot 90 \\
0.34 \\
2 \cdot 60\end{array}$ &  \\
\hline
\end{tabular}

* Relative risk of getting diabetes of G6PD deficient compared with non-deficient.

$\chi^{2}$ for association, three ethnic groups combined using the diabetic clinic controls $=11 \cdot 45, P=0.007$.

$\chi^{2}$ for heterogeneity between controls, $3.44,0.8$, and 3.75 , respect $\vec{\omega}$ ively, for Chinese, Indians, and combined groups $(P=0.08,0.59$, ang $0 \cdot 15$, respectively).

(1970). The higher incidence of G6PD deficiencis among non-diabetics of the diabetic clinic compare to the published series (Vella, 1961; Saha and" Banerjee, 1971a, b) may be the result of the presenco of prediabetics in the series.

It has been reported that glucose tolerance ip altered in subjects with G6PD deficiency (Chano mugam and Frumin, 1964) and the level of reduce $\overline{8}$ glutathione in blood of diabetics is decrease $\$$ (Illing et al., 1951). In view of the above findings one needs to guard against the possible inhibitory effect of diabetes on G6PD levels of red cells, indicating the screening test as deficient. However, Belfī̄ et al. (1974) reported an increase of G6PD actint in the liver of maturity onset diabetic subjectso Five of the diabetic patients of the present series showing G6PD deficiency on the first visit were followed up and they were found to be G6PLF deficient on subsequent tests, even when theiB disease was under control. Therefore, it seems very unlikely that diabetes per se produces G6PD. deficiency as detected by screening tests with brillian cresyl blue dye. Because of the empirical nature of the dye decoloration test, it needs to be confirmed by parallel G6PD assay that diabetes by itself does not lower the activity of G6PD in red cells.

The present diabetic series is representative of the population of Singapore, as shown by the highef incidence of diabetes among Indians, which corro $\rightarrow$ borates the findings of Cheah et al. $(1972,1975)$. Ir?

Table 1a Distribution of G6PD deficiency in diabetes mellitus

\begin{tabular}{|c|c|c|c|c|c|c|c|c|c|}
\hline \multirow[t]{2}{*}{ Ethnic origin } & \multicolumn{3}{|c|}{ Diabetes mellitus } & \multicolumn{3}{|c|}{ Diabetic clinic controls } & \multicolumn{3}{|c|}{ Population controls } \\
\hline & No tested & No deficient & $\%$ deficient & No tested & No deficient & $\%$ deficient & No tested & No deficient & $\%$ deficient \\
\hline $\begin{array}{l}\text { Chinese } \\
\text { Malays } \\
\text { Indians } \\
\text { Total }\end{array}$ & $\begin{array}{r}422 \\
66 \\
121 \\
609\end{array}$ & $\begin{array}{r}44 \\
3 \\
12 \\
59\end{array}$ & $\begin{array}{r}10.42 \\
4.55 \\
9.92 \\
9.69\end{array}$ & $\begin{array}{r}523 \\
87 \\
137 \\
747\end{array}$ & $\begin{array}{r}26 \\
6 \\
4 \\
36\end{array}$ & $\begin{array}{l}4 \cdot 97 \\
6 \cdot 89 \\
2 \cdot 92 \\
4 \cdot 82\end{array}$ & $\begin{array}{c}3312^{*} \\
1384^{*} \\
362 \dagger \\
5058\end{array}$ & $\begin{array}{r}111 \\
28 \\
6 \\
145\end{array}$ & $\begin{array}{l}3 \cdot 35 \\
2 \cdot 02 \\
1 \cdot 66 \\
2 \cdot 87\end{array}$ \\
\hline
\end{tabular}

*Saha and Banerjee (1971a); †Saha and Banerjee (1971b). 
view of the lack of association of G6PD deficiency with diabetes in Malay patients in the present series and in our earlier series (Saha, 1971), further investigations with larger samples are advisable to reach a definite conclusion. Further, it will be interesting to look into the phenotypic distribution of G6PD in diabetes mellitus in different populations, as there are many populations with a high incidence of diabetes but with low frequency of G6PD deficiency or none at all. The underlying significance of the association of G6PD deficiency with diabetes mellitus is not clear at the moment.

\section{ABO BLOOD GROUPS}

Table 2 shows the distribution of $\mathrm{ABO}$ blood groups in Chinese, Malay, and Indian patients compared to normal controls. There was no significant difference in the distribution of $\mathrm{ABO}$ blood groups between the patient and control series in any of the ethnic groups. There seems to be no real association present. The conflicting reports in the various published series may be because of the heterogeneity between patient and control series. The present study is unique in the sense that Singapore is served by only one blood bank and a parallel control series has been investigated blindly using non-diabetic patients attending the same clinic.

\section{HAEMOGLOBIN TYPES}

The incidence of abnormal haemoglobins in diabetic patients was: $0.24 \%$ in Chinese, $4.54 \%$ in Malays, and $0.83 \%$ in Indians, compared to $0.00 \%$ in Chinese, $3.45 \%$ in Malays, and $0.73 \%$ in Indians in the control series of the diabetic clinic, and $0.64 \%$ in Chinese, $5.52 \%$ in Malays, and $1.10 \%$ in Indians in the published series of Saha et al. (1973). All the abnormal haemoglobins were of phenotype AE. In the present series there was no significant difference in the incidence of abnormal haemoglobins between the patient and control series.

The author is grateful to the Medical Superintendant of the Tan Tock Seng Hospital, Singapore, for permission to carry out this study and to Professor E. N. Somerville for reading the manuscript.

\section{References}

Andersen, J., and Lauritzen, E. (1960). Blood groups and diabetes mellitus. Diabetes, 9, 20-24.

Belfiore, F., Romeo, F., Napoli, E., and Lo Vecchio, L. (1974). Enzymes of glucose metabolism in liver of subjects with adult-onset diabetes. Diabetes, 23, 293-301.

Berg, K., Aarseth, S., Lundevall, J., and Reinskou, T. (1967). Blood groups and genetic serum types in diabetes mellitus. Diabetologia, 3, 30-34.

Chan, K. T. (1962). The ABO blood group frequency distribution of Singapore based on a blood donor sample. Singapore Medical Journal, 3, 3-15.

Chanmugam, D., and Frumin, A. M. (1964). Abnormal glucose tolerance response in erythrocyte glucose-6phosphate dehydrogenase deficiency. New England Journal of Medicine, 271, 1202-1204.

Cheah, J. S., Tambyah, J. A., and Mitra, N. R. (1972). Prevalence and causes of glycosuria among the ethnic groups in Singapore. Singapore Medical Journal, 13, 273-279.

Cheah, J. S., Tambyah, J. A., and Mitra, N. R. (1975). Prevalence of diabetes mellitus among the ethnic groups in Singapore. Tropical and Geographical Medicine, 27, 14-16.

Craig, J., and Wang, J. (1955). Blood groups in diabetes mellitus. Glasgow Medical Journal, 36, 261-266.

Illing, E. K. B., Gray, C. H., and Lawrence, R. D. (1951). Blood glutathione and non-glucose substances in diabetes. Biochemical Journal, 48, 637-640.

Kessler, I. I. (1970). A genetic relationship between diabetes and cancer. Lancet, 1, 218-220.

Klebe, J. G., and Nielsen, J. C. (1972). The ABO and Rhesus blood groups of diabetic mothers and their new-born babies. Human Heredity, 22, 294-300.

Lamba, D. L., Singha, P., and Chandra, S. (1974). A study of diabetes in relation to blood groups and cholesterol levels. Humangenetik, 23, 51-58.

Macafee, A. L. (1964). Blood groups and diabetes mellitus. Journal of Clinical Pathology, 17, 39-41.

McConnell, R. B., Pyke, D. A., and Roberts, J. A. F. (1956). Blood groups in diabetes mellitus. British Medical Journal, 1, 772-776.

Motulsky, A. G., and Campbell-Kraut, J. M. (1961). Population genetics of glucose-6-phosphate dehydrogenase deficiency of the red cells. Proceedings of the Conference of Genetic Polymorphism and Geographic Variation in Disease. Grune and Stratton, New York.

Naik, S. N., and Anderson, D. E. (1971). The association

Table 2 Distribution of $A B O$ blood groups in diabetes mellitus

\begin{tabular}{|c|c|c|c|c|c|c|c|c|c|c|c|c|c|c|c|c|c|c|}
\hline \multirow{3}{*}{$\begin{array}{l}\text { Blood } \\
\text { groups }\end{array}$} & \multicolumn{6}{|c|}{ Chinese } & \multicolumn{6}{|c|}{ Malays } & \multicolumn{6}{|c|}{ Indians } \\
\hline & \multicolumn{2}{|c|}{ Diabetes } & \multicolumn{2}{|c|}{$\begin{array}{l}\text { Diabetic } \\
\text { clinic controls }\end{array}$} & \multicolumn{2}{|c|}{ Controls* } & \multicolumn{2}{|c|}{ Diabetes } & \multicolumn{2}{|c|}{$\begin{array}{l}\text { Diabetic } \\
\text { clinic controls }\end{array}$} & \multicolumn{2}{|c|}{ Controls* } & \multicolumn{2}{|c|}{ Diabetes } & \multicolumn{2}{|c|}{$\begin{array}{l}\text { Diabetic } \\
\text { clinic controls }\end{array}$} & \multicolumn{2}{|c|}{ Controls* } \\
\hline & No & $\%$ & No & $\%$ & No & $\%$ & No & $\%$ & No & $\%$ & $N o$ & $\%$ & No & $\%$ & $N o$ & $\%$ & No & $\%$ \\
\hline $\begin{array}{l}\text { O } \\
\text { A } \\
\text { B } \\
\text { AB } \\
\text { Total }\end{array}$ & $\begin{array}{r}208 \\
136 \\
117 \\
22 \\
483\end{array}$ & $\begin{array}{r}43 \cdot 06 \\
28 \cdot 16 \\
24 \cdot 22 \\
4 \cdot 55\end{array}$ & $\begin{array}{r}227 \\
144 \\
125 \\
30 \\
526\end{array}$ & $\begin{array}{r}43 \cdot 16 \\
27 \cdot 38 \\
23 \cdot 76 \\
5 \cdot 70\end{array}$ & $\begin{array}{c}6644 \\
3967 \\
3814 \\
837 \\
15262\end{array}$ & $\begin{array}{r}43 \cdot 53 \\
25 \cdot 99 \\
24 \cdot 99 \\
5 \cdot 48\end{array}$ & $\begin{array}{r}27 \\
23 \\
12 \\
4 \\
66\end{array}$ & $\begin{array}{r}40.91 \\
34.85 \\
18.18 \\
6.06\end{array}$ & $\begin{array}{r}30 \\
25 \\
23 \\
9 \\
87\end{array}$ & $\begin{array}{l}34 \cdot 48 \\
28 \cdot 74 \\
26 \cdot 44 \\
10 \cdot 34\end{array}$ & $\begin{array}{r}2098 \\
1369 \\
1596 \\
398 \\
5461\end{array}$ & $\begin{array}{r}38 \cdot 42 \\
25 \cdot 07 \\
29 \cdot 23 \\
7 \cdot 29\end{array}$ & $\begin{array}{r}51 \\
27 \\
37 \\
6 \\
121\end{array}$ & $\begin{array}{r}42 \cdot 15 \\
22 \cdot 31 \\
30 \cdot 58 \\
4 \cdot 96\end{array}$ & $\begin{array}{r}56 \\
29 \\
44 \\
8 \\
137\end{array}$ & $\begin{array}{r}40 \cdot 88 \\
21 \cdot 17 \\
32 \cdot 12 \\
5 \cdot 84\end{array}$ & $\begin{array}{r}1951 \\
1051 \\
1680 \\
318 \\
5000\end{array}$ & $\begin{array}{r}39.02 \\
21.02 \\
33 \cdot 60 \\
6 \cdot 36\end{array}$ \\
\hline
\end{tabular}

*Chan (1962) 
between glucose-6-phosphate dehydrogenase deficiency and cancer in American Negroes. Oncology, 25, 356-364.

Saha, N. (1971). Diabetes and glucose-6-phosphate dehydrogenase deficiency. Abstracts of the Fourth International Congress of Human Genetics, Paris, 1971.

Saha, N., and Banerjee, B. (1971a). Erythrocyte G-6-PD deficiency among Chinese and Malays of Singapore. Tropical and Geographical Medicine, 23, 141-144.

Saha, N., and Banerjee, B. (1971b). Incidence of erythrocyte glucose-6-phosphate dehydrogenase deficiency among different ethnic groups of Indians. Human Heredity, 21, 78-82.
Saha, N., Toh, C. C. S., and Ghosh, M. B. (1973). Genetich association in myocardial infarction. Ethnicity; ABO, $R h$ $\mathrm{Le}^{\mathrm{a}}, \mathrm{Xg}^{\mathrm{a}}$ blood groups; G6PD deficiency, and abnormaP haemoglobins. Journal of Medical Genetics, 10, 340-345. Vella, F. (1961). The incidence of erythrocyte glucose-6es phosphate dehydrogenase deficiency in Singapore Experientia, 17, 181-182.

Requests for reprints to Professor N. Saha, Faculty of Medicine, University of Khartoum, POB 102 Khartoum, Sudan. 